\title{
Cultism and Violence in Nigerian Universities: A Paradigm for Achieving Religious Academic Excellence
}

\author{
Ushe Mike Ushe (Corresponding author) \\ Associate Professor of African Traditional Religion \\ Department of Religious Studies, National Open University of Nigeria \\ Jabi, Abuja, Nigeria \\ Tel: 234-803-4512-751Ｅ-mail: mike.ushe@yahoo.com
}

Received: November 24, 2019 Accepted: December 12, 2019 Published: December 24, 2019

doi:10.5296/ijch.v6i2.16127ＵRL: https://doi.org/10.5296/ijch.v6i2.16127

\begin{abstract}
Nigerian universities and other institutions of higher learning have in recent times witnessed unprecedented insecurity, persistent violence and educational backdrop, leading to loss of many lives and properties worth millions of naira across the country. Part of the face out of this scourge is the prevailing case of cultism and other forms of violence in Nigerian universities and other higher educational institutions. This has resulted to gruesome arrest, expulsion and murder of many students on account of cult activities on the campuses and other forms of students' violence which further exposed our universities to insecurity, ritual murders, drug abuse and use of dangerous weapons by cult groups, victimization and regime of terror against fellow students, lecturers, and anyone that stands in the ways of these cult groups on our campuses. This paper discusses the impacts of cultism and other forms of violence on university campuses in Nigeria as a search for achieving sustainable peace and academic excellence. To explore this change, the study employs survey design, questionnaires and face-to-face interviews in collecting data and analysis. The research findings have shown that cultism and other forms of violence are prevalence in Nigerian universities and have increased tremendously in recent decades, reoccurring almost on daily basis. The paper observed that students' radical activism and union politics, incapability of university and state authorities to enforce minimum standard of students' civil behaviors on campuses as well as rivalries between cult groups and the wider campus community has drastically affected educational or academic performance of students in contemporary
\end{abstract}


Nigerian society. The paper recommends the restructuring of university educational policies and curriculum, provision of moral education and non-interference of the government and university authorities in the affairs of students' union politics and activism.

Keywords: Cultism, Universities, Students, Peace and academic excellence

\section{Introduction}

The phenomenon of cultism and violence in Nigerian universities existed since the 1950s. Although the origins of cultism and violence are not recent in the Nigerian universities, the gruesome situation experienced today has left several unanswered questions for many in the country. In the wake of such events, an intense focus on cultism and violence in Nigerian universities has been on increased and an ultimatum was given to vice-chancellors to eradicate cultism on campuses and other forms of violence within three months or face the wrath of the government. Thus, some states governments such as Rashidi Ladoja, the former Governor of Oyo state, made "good score" from a psychological test as a precondition for admission into the Ibadan polytechnic and measure in curbing cultism and violence on the campuses (Jamiu, 2008).

Eradicating cultism and other forms of violence on our campuses also required the eradication of the agents, agencies, and social contexts that produce and reproduces it. This means that we need to understand the dynamics of these broad societal and internal campus-based forces that produce and reproduces cultism and other forms of violence. We also need to inquire into the role of some highly placed members of our society such as patrons, sponsors, politicians, lecturers and highly placed persons in the government as well as military and paramilitary personnel located within and outside our campuses.

We should be bold enough to take on broader social forces like student's material conditions, interference in students' union affairs, the repressive and extortionate practices of academic and other university staff, insecurity within and outside campuses, worsening conditions of teaching and in some clear instances, ritualistic techniques in the demobilization of radical activism on universities, campuses (Dzurgba, 2010). Such measures are necessary for the vice-chancellors and heads of other higher educational institutions to take in eradicating cultism on our campuses in the country. They should like surgeons adopt these approaches to discontinue the rampart cases of the phenomenon of cultism and violence that the state itself has been a central party to it in Nigerian universities.

In dealing with the phenomenon of cultism and other forms of violence on our campuses, therefore, we are duty bound as scholars to critically inquire into their antecedents, analyze these antecedents in the light of broader historical dynamics within and outside universities, identify the main interests behind them, and project their nicely implications for higher education in Nigeria. In the past two decades, cultism and other forms of violence have become major threats to peace, religiosity and pursuit of center goals of higher education.

Cultism is now firmly established in public discourse, reports of conflicts manifested in deadly violence between rival groups of cultists, vigilantes, or criminals on the one hand, and the wider university community on the other and it is becoming frequent news items from 
universities. The nature, scale and intensity of cult practices vary from one university to another, but without exception, wherever these practices gained roots, general condition of fear, insecurity and paralysis of authority are palpable. From the campuses of Nigerian universities like Lagos, Nsukka, Ekpoma, Ibadan, Benin, Jos, Ile-Ife, Abuja, Port-Harcourt, Makurdi and Otukpo, among others, cultism have claimed several lives and properties worth millions of naira. Cultism has limbed academic staff and students, thereby directly affecting teaching, learning, and research in Nigerian Universities. Even more disturbing, is the intricate relationships between cult practices on universities campuses and the wider structure of power in the society as demonstrated in various cases in the country. The most celebrated example of such cases is that of the University of Abuja where most of the twenty-two students arrested on account of cultism and other forms of violence were released subsequently on "orders from above". These unfolding events have been persistent that it has drawn the attention of well-meaning and concerned Nigerians. This paper examines three major claims or arguments about the nature of cultism and violence in Nigerian Universities.

First, the rise of cultism in the nation's higher educational institutions inversely related to the degree of radical activism on our campuses. This assumption begins from the simple observation that we need to examine why cultism started gaining ascendancy notoriety at about the sometime radical activism started declining on campuses and one cannot but help draw the conclusion that these processes may not be independent of one another. The paper argues that the state, in response to the growing radical activism both from staff and students, especially as from the late 1970s, employed various techniques to demobilize, defuse, and control radicalism, prominent among which was reliance on cults as demonstrated by events at the university of Nigeria, Nsukka, the university of Jos, and the university of Ibadan.

Second, that the success of the strategy of eradicating cultism in Nigerian Universities and other institutions of higher learning depends in part on the internal contradictions of the radical movement itself, and the way radical activism imploded onto itself in response to wider social forces within and outside the university system (Kuna, 2003). The several mechanisms employed by the States and Federal Government have serious effects on the development that could be categorized as multiple modes of livelihood"(Mustapha, 1991). Dismissal and expulsions of academic teachings that are not paid or sponsored to learn, the erosion of university autonomy and the imposition of a generalized and antiseptic social science curricular and declining budgetary allocations to university education generally (Kuna, 1996). More so, the impacts of the structured adjustment programmer on universities, and on the society are still yet to be seriously researched.

Third, that a number of broader concrete societal forces such as worsening material conditions, growing dominance of militarism and insecurity, the reconfiguration of student identity, the erosion of professionalism, the intensification of the dismal disease, the crises of values, and the challenges brought upon the reward system in which the worst (criminals, hoodlums and opportunists) come to corner societal resources more than "straight" people have all contributed to the eclipse of logic and reason and the ascendency of the fetish on our campuses and the wider society at large. In recent times, there have been frequent reports from several dailies of ritual murders, trade in body parts, and ritual practices indicative of a 
scope beyond campus boundaries. These negative events acted as stimulant to this research work. The paper therefore, discusses the causes, the origins and the transformation of radical activism into opportunistic students' unionisms, and proffers suggestions on the way forward.

\section{Conceptualizing Cultism, Violence, University, Students, Religious Excellence and Nigeria}

The concept of cultism has become a dominant issue in popular discourse to the extent that its meaning is generally taken for granted. Cults are similar to many of the world's established religions in the early phases of their development. According Kelley (2001), Cult can be defined as:

... a particular structural type of religious institution. Membership is predominantly lower class and usually gained during an emotional crisis that joining a cult is seen to resolve, unlike other religious institutions, cults tend to be short-lived, primarily because of their structure-an informal, loose organization formed around a single leaders' charismatic authority highly emotional services that lack formalized ritual; and a retreaters, hostile orientation to major social institutions.

Looking at this definition it is clear that both cults and religions share some common characteristics. A distinction must, therefore, be drawn between practices that are integral parts of all major religions and specific practices ordinarily referred to as cultism. Cultism is a way of thinking oriented toward an unquestioning revolve around a single, "all knowing" leader whose ideas must be taken as supreme and final (Kuna, 2003). Cultism oppose to reason and logic that forces a sense of awareness, perception of the real, and the organization of observational data, and it force adherents to repress, negate their own ideas and eradicates contradictions, rather than engaging or attempting to explain them. Based on this that cult is contrary to religion which is a form of intricism which holds that facts are revealed to us and the mind is a passive mirror, absorbing the truth by revelation or the unthinking acceptance of authority.

Unlike established religions, cults are loosely organized and tend to rely mainly on the charisma and ingenuity of their leaders. It thrives on allegiance either to an idea or to a leader and promotes an unquestioning attitude in members. Cultism in the context of this paper can therefore be defined as:

A secret organization shrouded in secrecy, undisclosed information by the members and blood oath taking. Their members" individual identity and activities are strictly kept secret from non-initiates; they hold their meetings and carry out their operations in the night. They also gave signs and symbols for member's communication, instructions, directives, commands, and have minimal activities in broad day light. The secrete nature of cult members make people to regard themselves as "nocturnal societies (Adejumobi, 2005)

In many Nigerian Universities, students cultists seek to acquire or exercise a great deal of power so as to compel and coerce university admistrators, professors, lecturers and students to do their will in immoral and criminal circumstances such as examination fraud, 
disciplinary offence, rigging election, extortion of money and property from fellow students as well as monopoly of by girlfriends to both indigent and source of income, and the new and junior members are expelled and forced to bring large sums of money and property from their fellow students, parents, relatives and the general publics (Beckman, 2005). To have these things, threats, intimidation and harassment of non-members in order to extort money from them becomes the norm, approaching the "state of nature" so graphically described in Hobbes' the leviathan. Cults are broadly classified into five groups, depending on the techniques of mind control and their most dominant activities. These include:

(i) Religious Cult: This group of cultists draw inspirations from some major monotheistic religions such as Christianity (Mormons and Jehovah Witnesses), Islam (The Assassins) Eastern religious experiences such as Hare Krishan Movement, organizations with esoteric or illuminist orientations (Rosicrucian) or fetish practices embedded in traditional religions such as those of the Ogboni Society (Nigeria), the Bwite (Central Africa), Jurema (Brazil) and Voodoo Cults (Haiti).

(ii) Political Cult: It draws inspirations from ideological extremes, left and right (neo-Nazi organizations).

(iii) Psychotherapy Cult: This group of cultists tends to draw inspirations from persona; enlightment and appeal to a "higher order" (Scientology, or the Astral travel of Lobsang Rampa).

(iv) Commercial Cult: This group seeks to secure and protect commercial interests and advantages such as skills and techniques of production and swear their members to strict oaths of secrecy, have strict leadership codes, and armed wings that enforce decisions within and of the group. For example, the Onitsha market Trader's Association (OMATA) in South-Eastern geo-political zone of Nigeria.

(v) Criminal and Drug Cult: It is a criminal and semi-criminal organization engaged in a wide-range of practices, spanning the licit and illicit, and which also strictly enforce oaths of silence on members, have unique recruitment practices, and adopt certain behavioural repertoires such as dress codes, slang, drugs, among others, to achieve a religious or ritualistic experience.

In all these groups of cultism, certain-cultural practices, sexual permissiveness, and drugs use are usually key elements of adherence by their members, although the degree to which these manifest is also a function of a host of complex factors which includes: the nature of leadership, the goals of the group, the group's ideology the extent to which it is able to construct a coherent syncretistic ideology and its membership.

Cultism establishes dominance over member's environment (dress codes), lifestyles, feeding schedules, periods of worship and where to live and manipulate their thoughts (on unquestioned and unquestionable beliefs, rather than on reason and logic). In addition, through a complex manipulation of guilt, fear and the denial of vital information (strict control of all media or contact with the outside world, cuts seek to suppress logic and rational judgments, thus, establishing control over members emotions and thoughts. Like other forms 
of deviance cultism is learned in the contexts where potential cultists had sufficiently disengaged form broader conventional behaviours/practices against it, which at the same time imbibing specific behaviours and practices that promote cultism (Sutherland, 1976). In contemporary Nigeria, worsening material conditions of existence have given rise to a range of morbid practices that have had serious impacts on the value system in general.

It is therefore, no doubt an over-exaggeration to say that the generalized insecurity across the country and institutions of higher leanings today emanates directly from these conditions, and the state's declining capabilities, especially in the provision of security is a graphic demonstration of this phenomenon. Consequently, individuals and communities across Nigeria no longer feel safe, resulting in the rise of vigilantism and other non-state forms of security that may have significant connections with cultism. This privatization of security is a serious by-product of state incapability to provide solution to the problem of insecurity in Nigeria. As a result, this prompts reactions across the country about the neo-liberal economic and political programmes that "draw on idioms of accountability rooted in the supernatural" (Smith, 2004). Violence on the other hand, is a term used inter-changeably with conflict perpetrated by the student cults in the universities.

David (2007), cited in Ugbudian (2015) defined violence as the pursuit of incompatible interests and goals by different groups in Nigeria. In the context of this study, violence can be defined as:

The use of threat carried out by individuals or students within the universities against others with the intent to cause injury or death to persons and/or damage or destruction to property, and whose objective, choice of targets or effects have socio-political and educational significance. (Ochoche, 1977)

University violence is the employment of force by cult's students to intimidate their opponents, professors, lecturers, new students and the general publics in universities in Nigeria (Anifowse, 1982). Violence is broadly categorized in the social violence, political violence, religious violence and economic violence. All these are caused by several factors such as: violence arising from electoral malpractices, poor material conditions of students, oppressive and exploitative leadership, fear of felling examination, frustration, greed, monopoly of male and female friends, and clashes between the different groups, among, others (Okafor, 2003). All these factors may compel university students to seek redress as a member of secret cult. While some university students who do not belong to any of these secret cult groups, take the position of diehards in their fight against university authorities, leaders and sponsors of the different secret cult organizations on the campuses of Nigerian Universities.

We conceptualize University as an educational institution at higher level of learning where a person studies for a degree. It is the process through which one's mind develops through the process of learning in the school, college or University. Education in this context is the knowledge and skills a person acquires from being taught (Dibua, 2004). It is acquisition, management and application or utilization of knowledge and skills by a person. A University 
student therefore, referred to "someone who is studying at a university or other educational institutions of higher learning" (Dzurgba, 2004).

The Joint Admission and Matriculation Board JAMB (2002) defined a university student as "someone who has reached the age of at least 16years old on the first day of his/her entry into the university, usually in the month of September or October of any given academic year" University student in the context of this paper, can therefore, be defined as "Someone who acquires knowledge and skills in university or other educational institutions of higher learning in his or her chosen discipline" (Dzurgba, 2004). This means that a student who has entered the university is no longer a child, but an adult. A university student is matured enough to be held responsible and accountable for his or her actions, deeds, thoughts and actions or utterances. This means that a university student is subject to laws and regulations of the university authorities.

Thus, a university student is subject to the university's law, regulations, authority and power. It is in this context that the university student claims his/her right to matriculation number and studentship while he/she pledges his/her patriotism and loyalty to the university (Adesogan, 2002). However, the university student is a youth in many cases. He/she is a young person, a teenager and an adolescent. His/her personal characteristics govern his/her perception, thought, speech and action (Beardsmore, 1969). He/she is full of emotional instability, personal insecurity, social idealism, vision, capabilities, claim to absolute knowledge, restlessness and motion. He/she is not interested in issues of old age, experience, tradition, convention and restriction, but fun-making, dignity, honour, respect, prestige, popularity, styles, fashions, religion and marriage (Bremer, 1967). And in pursuit of his interest in youthful manner, a student willfully breaks laws, violates regulations and defies constituted authority without a sense of trouble, danger, problem, risk, difficulty, impossibility, uncertainty, frustration and penalty. $\mathrm{He} /$ she rejects personal limitations on a belief that everything is possible to him/her. He/she sometimes sees discipline and self-control as inhibitions to his/her own aspirations (Adesogan, 2002).

On the other hand, there is an adult student who has matured and gained experience through travelling, interaction, friendship, marriage, work, business or politics. He/she has learnt useful lessons through suffering, agony, pain, anguish or penalty due to his/her past youthful restlessness, and now knows the dangers and consequences of lawlessness and recklessness. $\mathrm{He} /$ she acknowledge his/her limitations and appreciate the value of discipline. For him/her certain things are difficult, while others are impossible. He/she is rational and realistic in his/her conduct. In fact, an adult student is the reverse of the youth university student (Crabb, 1979). He/she is responsible and accountable for his/her thoughts, words and deeds. But unfortunately, most of the university students are youths and from their behavioural characteristics, one may be tempted to label them as utopians, dreamers, militants, rebels, radicals, fanatics, confrontations, anarchists, recalcitrant, intransigents, nihists, thugs, arsonists, hooligans and the lawless. Most of the youthful students do not belong to these undesirable social groups. 
This is why there are handful of diehards students in our universities today, that may be redeemed through religion or counseling, and eventually graduates as having been found worthy in character and learning. He/she imbibes the scientific ethics made up of truth, honesty, objectivity, and is curious to fight against cultic activities on the campus.

\section{The Agony of Nigerian Universities}

The decay situation of educational system has presented a very sad, painful and unpleasant state of affairs in Nigeria in the last two decades. The persistence level of violence, strikes, cultists' activities on campuses and non-payment of staff salaries are factors that not only serve as agony of the Nigerian universities and other institutions of higher learning but also ridiculed academic excellence in the country. With the rise of cultism in tertiary institution across the Nigerian universities, violence and bloodshed have become the order of the day. The persistent violence perpetuated by different groups of cultists has aggravated violence, intimidation, and harassment which threatens and forces some staffs and innocent students to do their will. The easy access of these cultists to sophisticated weapons, desire for material wealth, and quest for power made them to inflict a regime of terror on Professors, Lecturers and students who are not their members.

Also the immoral and criminal behaviours exhibited by the cult groups such as examination fraud, disciplinary offences, rigging of election, extortion of money and properties from fellow students that are not members and monopoly of boy-girl friends are other factors that contributed to the agony of universities in Nigeria (Dzurgba, 2004). The questions many do ask are: What are the objectives of cultism in the universities in Nigeria? Why have they flourished in Nigerian Universities? How can peace and academic excellence be achieved in Nigerian universities? These questions and other related ones presents uncalled for situation which ought to be properly addressed in this paper. It must be noted here that prior to emergence of cultism in Nigerian tertiary educational institutions, the universities were serene places of acquiring knowledge and skills for the survival of the individuals in the society and, human capacity building and improvement of comfort of the learners. Teachers and students were well paid; students were well taught and cared for in all things necessary for the growth and development of the Nigerian society.

The need for learning was the main priorities of the universities and other educational higher institutions of learning in the nation. Nigerians realized that no nation in the world can rise or developed above its intellectual capacity unless their educational system is well established. However, with the eclipse of principled activism, students' politics, power tussle between different cult groups, poor material conditions of students and the rise of opportunistic unionism in the $1980 \mathrm{~s}$, led to a drastic change in the status of the universities in Nigeria (Dzurgba, 2002). And to address this challenge, the university administration founded the armed groups which supported cult gangs for unionism. The involvement of police provoked students' opposition which escalated violence and wanton abuses of human rights, leading to the death of some students in Nigerian Universities (Post-Express, February 22 ${ }^{\text {nd }}, 1985$ ). Several universities like university of Benin, University of Nigeria, Nsukka, Ahmadu Bello 
University, Zaria, University of Jos, Obafemi Awolowo University, Ife, University of Ibadan and a host of others, experienced students' violence and bloodshed.

The involvement of the state in coordinating student's opposition built on the practices of existing cults and vigilante groups constituted a serious challenge on campuses in Nigerian universities today. Ubani (2005) posits that the formation of operation zero option (OZO) by the state government which consisted of final year students' did not help the matter either. The attacked on the vicious cult groups, abductions and intimidations of the officials of National Association of Nigerian Students (NANS) by operation Zero option (OZO) agonizes some of the universities in the country. This led to the dismissal, expulsion, rustication and death of many students and left-wing intellectuals in some Nigerian universities. Also, many campuses across universities became battle grounds between rival cult groups and the wider community. The unfolding of these events in the past two decades clearly shows that the universities in Nigeria passing through an agonizing period of cultists invasion and decadence of academic excellence in contemporary Nigerian society (Dzurgba, 1998).

To university authority, staff and wealthy students who are not secret cult members, cultism is a regular source of income. The cult leaders needs money and items such as standard clothes, shoes, refrigerators, television sets, radios, videos and furniture and to obtain them, the new and junior members are compelled and forced to bring large sums of money regardless of how they get the money. Sometimes, the clash between the different secret cults over control of funds, control of political power and students, control of representation and the show of supremacy on campus, demonetization and torture knowingly and unknowingly of other secret cult groups also spark violence in Nigerian universities. This often leads them to stealing money and property from their fellow students, parents, relatives and the general public who are non-members of secret cult groups.

Looking at the historical development of cultism, one could see that cultism is a phenomenon that is not recent in Nigerian Universities. The phenomenon has existed on our campuses since the late 1940s (Adewale, 2005). It has intricate interplay of psychological, historical and politico-economic factors that are internal to universities and the wider society. Cultism is crucial not only in understanding their dynamics, but also in formulating plans to combat them. Before the formation of Nigeria and the establishment of universities, many societies that constituted Nigeria had totemic rituals and religious practices that were properly represented by the term "cultism" (Dzurgba, 2004). In many parts of Nigeria such as south-west geo-political zone, the Ogboni society is for a long time and even today, one of the most dominant cult or religious organization.

Among the Efiks and Mende of Eastern Delta of South-South geo-political zone there are cult groups like the Ekpe, Poro and Ekine, while in North-Central geo-political zone, especially the central highlands of the present day Benue, Niger state, Plateau state, Kogi state, Nasarawa state and Kwara state, the practices surrounding masquerades and girinya ritual in certain cases, belong properly to the realm of cultism (Kuna, 2003). In contemporary Nigerian society, there are many splinters of secret cult groups as shown in Table 1 below: 
Table 1. Names, meaning and membership of cultism in tertiary institutions in Nigeria

\begin{tabular}{lll}
\hline Name & Meaning & Membership \\
\hline Pirates & Sea Robbers & Males and Females \\
Buccaneers & Sea Robbers & Males and Females \\
Black Axers & Criminal Destroyers & Males and Females \\
Vikings & Armed Robbers & Males and Females \\
Mafia & Secret Society of Criminals & Males and Females \\
Amazons & Female Warriors & Females \\
Jezebels & Wicked Women & Females \\
Black Angels & Wicked Agents & Males and Females \\
Queens of the Air & Wicked Agents & Females \\
Eiye & Preying Birds & Males and Females \\
Ku Klux Klan (KKK) & Society of Racists & Males \\
Pink Ladies & Criminal Women & Females \\
\hline
\end{tabular}

The activity of these secret cult groups presupposes a rise in splinter of different cult groups in Nigerian Universities. The earliest confraternities on campuses were branded for any activity that constituted resistance to colonialism. However, the internal dynamics of the confraternities, in the immediate and changing contexts of campus politics and the wider society brought impacts which led to several splinter groups of cultism with personal, ideological and other similar tensions on the campuses of universities in Nigeria.

\section{The Root of Cultism and other Forms of Violence in Nigerian Universities}

Cultism in Nigeria universities has a long history. The phenomenon became more prone all forms of violence in tertiary institutions of learning in the 1980s with the emergence of radical activism and the rise of opportunistic unionism. This culminated in the formation of several unions to establish a just order and to control students' activism in Nigerian Universities. This took place in four phases; Phase 1 began with role of students' activism in colonial struggles through the West African Students Union (WASU) in 1954, and National Union of Nigerian Students (NUNS) in 1954. Most of its leadership played dominant roles in the struggles of their own countries (Beckman, 2005, Daddieh, 1996). Phase 2 which started from 1954 to 1978 was a phase that laid the grounds for students' movements in subsequent years, especially in 1978. The III Phase lasted from 1978 to 1996 and no phase before it has been critical in establishing an ideologically coherent and organizationally robust radical student's movement (Kalu, 2005).

It was also during this phase that the state came to construe radical activism in general and students' activism in particular as one of its greatest threats. Phase IV began from 1996 to the present moment and it is a period of decline of radical students activism and the rise of gross opportunism; a phenomenon that was graphically demonstrated in the rally organized by National Association of Nigerian Students in support of the infamous third term agenda (Ayu, 1996). In all these phases, with the singular exception, the third phase, students have been 
able to sustain high degree of organizational and ideological coherence in the face of state attempts at repression and cooperation. It was also in this phase that students firmly established a specific pan-Nigerian and anti-imperialist identity for themselves. This identity was nurtured and expressed through a series of repertoires that served as a platform for a sustained mobilization of the students' body against dominant interests. This was clearly and graphically demonstrated in the formation of several associations and political groups across campuses in Nigerian universities.

These associations include: Patriotic Youth Movement of Nigeria (PYMN), Movement for the Advancement of African Societies (MAAS), Movement for Progressive Nigeria (MPN), Movement Against Second Slavery (MASS), Marxist Socialist Movement (MSM), Marxist Youth Movement (MYM), and Patriotic Liberation Movement (PLM) to mention but a few. The most important struggles that shaped this very crucial era of students' activism were the anti-colonial struggle; the opposition to the Anglo-Nigeria Defence Pact; the Ali Must Go struggles of 1978; and the Anti-SAP struggles as from the late 1980s. The flourishing of the radical movement was paralleled and closely supported by the growth of radical intellectuals across campuses that were critical in providing necessary direction, support, and generally helped mobilize students to take on anti-imperialist causes. In the heydays of radical activism, left wing intellectuals and the NUNS offered a sustained and coherent identity to students across Nigeria, especially in its opposition to the state.

This opposition, contrary to dominant perceptions in government circles as a mere 'troublemaking' exercise, was in reality a fairly substantive and even if not totally coherent opposition to imperialism, manifested locally in opposition to the Structural Adjustment Policies as well as to military rule. The collapse of this radical identity therefore, was the role of the state and university authorities in their quest for the de-radicalization of campuses in general, and student politics in particular. The single most significant incident that provided the ground for this intervention on campuses was the generalized opposition to the Structural Adjustment Programme that began in 1986, and which led to the nationwide student crises that resulted in the loss of the lives of several students in Lagos and Zaria.

In an attempt to deal with a worker-student-academics nationwide strike in 1986, the then President, Gen. Babangida, equated such collective action with treason when he said in a broadcast to the nation, that 'what we are dealing with here is the civilian equivalent of military coup.' That pronouncement resulted in a backlash, and the government was looking for 'subversives' across the country, the most readily available targets being students and radical intellectuals. It is important to note here that, cultisms are satanic diabolical organizations. In the course of initiation of their new members, charms are prepared; invocations and blood oaths are taken. The initiates are also subjected to manhood tests in the course of which they are blindfolded, flogged with chains, battered and tortured. These processes help in no small way to brutalize and harden their members and them prone to violence and revenge and insensitivity to human sufferings (Bagu, 2005).

Cultism are prone to alcohol addiction and drug abuses, which make them to torture, maim, and rape their fellow students and other people on their fellow students and other people on 
the university campuses. They drink narcotics, and smoke Cocaine, Heroin, Marijuana, Cannabis, Crack and Morphine in search for pleasure, happiness, satisfaction and relief from guilt. Some of the cultists take narcotics drugs as a solution to academic, emotional and family problems as well as to help them forget their real problems for a little while and feel that life is full of pleasure. However, the elusiveness and temporality of that elusive pleasure cause them to go back to narcotic kiosks room, in hotels and forests again and again. As a result, the narcotic drugs affects their brains and nervous systems in a harmful way, gradually losing their brain capacities to know, think, reason, decide, choose and exercise free will. This form of illness is called "dementia". Such ill students no longer behave normally and would not respond positively to any kind of counseling.

Cult members need psychiatric treatment to restore their mental health and human faculties. These students' are diehards because they refuse to be advised, counseled and helped when they get involved in a violent conflict. Their goals are violence and bloodshed (Ibeh, 2005). Many of student cultists get involved with radical critics and human rights organizations which are established across the universities in Nigeria. The students' cult members believe that radical opinions, ideas and leadership should be accompanied by violence in order to compel and coerce others to give into their demands. Thus aggression, harassment and violence are the qualities of a radical secret cult person. He/she approves lawlessness and anarchism as appropriate attitudes and so cause physical, mental and emotional agony, pain, suffering and anguish to their non-members. Their adaptation of violent names such as "Aluta", "Two things", "Struggle", "Expioson", "Blast" and "Diehard", "Scorpion" are clear indications of radicalism. They turn hostels into republics such as "Katanga Republic" and "Angola Republic" to symbolize their political mission and endless struggle on campus Pamilusa (2002), cited in Dzurgba (2004).

Tuition and accommodation fees are the greatest causes of agony in which the university has been groaning and yelling annually. There are hostels or halls where secret cult members prefer to stay, and such fees have been expensive for students who are non-members to afford. Such hostels are perennial causes of violence in the universities. Additionally, Boy-girl friendship often constitute problem among the secret groups when another person is suspected of engaging in a relationship with any girl they admires on campus. As a result, the cultist becomes anxious, envious, jealous and selfish with the person who is also interested in the same he is already deeply involved or admired. This could result in a clash between the two boys or two girls in the case of men, leading to fractional conflicts, violence and bloodshed.

Sometimes, sexual harassment of the opposite sexes could trigger students' violence in the universities as a result of brutality, cruelty and aggressive tendencies of the cult members to intimidate innocent male or female students' resulting to violence on the campuses. Sexual harassment is an unpleasant behaviour which often threatens the personality, ideas and competence of a student in Nigerian universities. Many girls or boys have avoided, resisted, or rejected boys or girls who advanced for sexual affairs in all ramifications. In this sexual harassment male Cultists unleashed aspersions, contempt, shame, embarrassment and persecution upon female students with strong moral character. Cultism makes campus a 
nightmare for innocent students' who bluntly refused to join their groups. It is an ill wind currently blowing across the tertiary institutions in Nigeria and requires drastic measures to bring the disaster to a halt.

\section{Causes of Cultism and Other Forms of Violence in Nigerian Universities}

There are several factors responsible for the rise of cultism and other forms of violence in Nigerian universities. These include:

(i) Eclipse of student radical activism and the rise of opportunistic unionism. This was the presence of a sustained state of repression and insecurity within the universities and wider society. It was also the period of flushing radical movement supported by the growth of radical intellectuals across campuses that were critical in providing necessary direction, support and general help in mobilizing students to take on anti-imperialist opposition in Nigeria.

(ii) Desire for material wealth. The Nigerian university students needs money naturally and are selfish, greedy, and corrupt about money. They have often been found guilty of financial indiscipline, misappropriation and mismanagement as well as spending a huge sum of money without accounting for it. The students' cultist leaders are accountable neither to the university nor to the student union government. Therefore, students' often see campus politics as money making venture in which corruption is not a crime. The agony caused to several students, academics and administrators by cultists in the name of extortion, fraud, and destruction of properties are clear instances for the quest of material wealth.

(iii) Quest for power. Struggle for leadership position and control of the members are the major sources of power tussle among the different cult groups in Nigerian universities. Each cult group wants dominate the others and to be at the hem student affairs and other related ones in the universities. The struggle for power often generate high level of violence and bloodshed on the campuses, leading to expulsion, suspension and the death of innocent students, some of which are not members of the cult groups.

(iv) Clash of values. The bad manners and motives of cult groups create a situation of clash of value. The misbehavior of cultists to act generally condemnable in the society could be actions that are extolled by a section of the community but condemned by the other section of the community. Such situations constitute veritable source of continuing violence.

(v) Bad leadership. Nigeria has bedeviled with bad leaderships at all levels, including university authorities. This has led to improper and untruthful knowledge of affairs. Unjust structures have been set up which are brought to the limelight in the sharing of amenities and other facilities to students in Nigerian universities. The inadequate access to these facilities often make some student cultists to force students who are not their members to pay stipulated dues in order to enable them acquire the basic facilities needed for comfort on campuses in the universities. Some of these cultists are used by politicians as thugs for various purposes in order to pay them. Since the 
material condition of students in Nigerian universities is very poor, many gladly accept to do the job to better their condition of living on the campuses.

\section{Ways of Curbing Cultism and Violence in Sustenance of Religious Academic Excellence in Nigerian Universities}

The prevalence of cultism and other forms of violence in Nigerian universities is a thing of concern to many academicians. It is a well-known fact that most students who are members of the different cult groups follow the footsteps of their fathers or mothers because of the make-believe and utopian ideas they receive from their parents who belongs to cultic groups such as Ogboni, Free mansion, Black axe, Black Beret, Black Cat, Black Brassier, White angels, Daughters of Jezebel, Bra Bra, Amazons, and host of others. The primary objective for joining cultism are to be powerful, pass examination without working hard for them, win love of the most beautiful ladies on the campus, protection from other cult groups, and so forth. These cultic groups have impacted negatively on the university educational performance in the country.

The questions many ask are: What is the way forward? How can peace and academic excellence be achieved in Nigerian universities? What are the possible solutions in eradicating cultism and other forms of violence in Nigerian universities? The analysis of these questions will help us in proffering remedies to these problems. We have seen that the path to cultism and other forms of violence is the downward part. Going down the slope is usually easier than ascending a hill. It is therefore, my opinion that, in order to reduce the incidences of cultism and other forms of violence in Nigerian universities, we should take steps to revise this downward slope and encourage the natural progress towards matured, civilized and sophisticated ways of reacting to frustration or thwarting agents of cultism and other forms of violence in our university environment. Though they will occur as long as human live together and interact among one another, however, they seem to have great influence on our educational standard.

These are the forces behind universities agony today which call for urgent attention in addressing them. The first way forward is timely intervention by the government at all levels. Nigerian universities should be made serene places where people use their intellects as skills to develop ideas and moral behaviours for the survival and promotion of an excellent educational system in Nigeria. There should be prompt payment of teachers in order to encourage them focus and pay more attention to their duties. Priority should be given to the development of student intellectual capacities within the university system. The government should put in her best in improving the living conditions of Nigerian students' and lecturers; this will reduce the unserious attitude towards the attainment of excellent education in Nigeria. The tuition fees should be reduced in order to enable students from poor background to have easy access to tertiary education in the country. This however, will reduce youth restiveness and insecurity that have characterized Nigeria in recent times.

It is unfortunate that the entire educational system in Nigeria is in a state of alarm, and the slightest stimulus triggers off violence. It will be helpful if the lecturers of our institutions of higher learning could begin to pay more attention to the values and codes that are tantamot to 
promoting cultism and all forms violence all campuses of institutions of higher learning in the country. Educational institutions have the most formalized opportunities for accessing the reduction of cultism and violence in our country. As Ngoddy and Ilegbune have pointed out, people will stand up for their right in such ways as not to violet the rights of others. That is to say, they are able to handle thwarting or frustrating agents, no matter how difficult with assurance, while maintaining a good human relation with all concerned.

The universities with all the complexities of relations and the wonderful opportunities for deliberated guidance stand out among organizations and institutions that could develop strategies for reducing cultism and other forms of violence in our dear country, Nigeria. The government should empower them to perform this role. There is also the need to go back harness and adhere to the cherished cultural norms and values of our traditional Nigerian society, which we have thrown overboard in our unbranded question for modernity and Western civilization. To eschew cultism and violence that follows in their trail on the campuses as entrenched in country's constitution, educational questions, especially that of cultism and violence needs to be tackled with sincerity of purpose and momentum of actions to redress embittered feeling of deterioration in academic excellence in the universities and other institutions of higher learning in the country.

Efforts should be made to see that, resources are available for development of education that will make our students imbibe educational policies and curriculum in Nigeria. Nigerian students should learn from and idealize the melting-point experiences of other countries that maintain their educational standard as strictly applied constitutional provisions in educational matters. There should be spirit of co-orporation and collegiality in development of education in Nigeria. The leadership in Nigeria should endeavour to be competent, visionary and mass oriented in championing educational programmes that will better enhance that life of the learners in our universities positively (Kalu, 1995). In order to minimize students' political violence in Nigerian universities, a systematic programme of social and political education should be embarked upon in which time frame of elections and the participant should be groomed on the demands of university authorities and democratic political process as well as their electoral rights and obligations without government interference.

Efforts should also be made to ensure liberal education, gainful employment opportunities and good housing and medical care for staff and students in order to direct their youthful potentials, struggling energies and exuberance to more useful ends. Conceited efforts should be made to eliminate cultism and other forms of violence in institutions of higher learning in the country. The students most prone to cultism which include living perpetually under fear, the risk of losing one's life and admission or been suspended or expelled from the institution, the risk of losing future opportunities and discomfiture and danger of the violence that goes with cultism. Authorities at all levels of our tertiary institutions should mobilize efforts to ensure compliance to all rules and regulations against cultism on the campuses across Nigeria. The students should be counseled by counselors and religious leaders of the dangers of the cankerworms of joining secrete cults and generating violence in Nigerian universities.

Sessions should be organized during which cultists will be persuaded to renounce their 
membership of cult and participation in all forms of violence in educational institutions of higher learning in Nigeria. Government security agencies, especially the police and the state security services should deal ruthlessly with all proven cases of cultism and violence in Nigerian universities and the society at large. Conceited efforts should be made by the Government to create a vigorous and critical academic atmosphere that engages students and encourage staffs who hardly want to stay any longer in lecturing and those who stick to lecturing as an alternative option because of lack of job opportunities in the country. Even those who want to remain do so not because they want to, but because they either cannot move, or there is no place for them to move to. The university authorities should encourage professionalism by discouraging lecturers who extorts money from students' through the sales of handouts, books and lecture notes as well as demand gratification. This situation generally supports hostility, erosion and decadence of intellectualism and professionalization of education in contemporary Nigerian society.

Also, revitalization of students' activism should be entrenched to help in directing the energies of students for socially useful purposes. Intensive efforts by the liberated and conscious students' across the students' bodies on our campuses should be started to revive some of the organization that were founded since 1980s that can provide students with a coherent Pan-Nigerian identity. This task also belongs to academic staff, since they were central in ensuring mobilization of students. Combatting cultism and other forms of violence in the campuses requires the assistance of all and the wider Nigerian society. The state must provide adequate legal frame works for sanctioning the practices of cultism and other forms of violence in Nigerian universities. Such sanctioning should be sponsored and financed by the government and university authorities must be empowered to deal with these cases.

\section{Conclusion}

In our foregone discussion, we noticed that cultism and other forms of violence are common phenomena responsible for agony of Nigerian universities in recent times. They are found in almost every tertiary institution of higher learning in our country. Most of the violence on our campuses comes within and there is tendency for every cultists group to strike back, or to defend oneself when attacked or threatened. Cultism and violence are not practices of university cultures, however, their prevalence on campuses of Nigerian universities, have made it part and parcel of educational problems confronting our country today.

We have seen in the cases of some universities that practices such as rape, murder, arson, acid bath, violence of other forms and illegal possession of weapons have easily become part of university culture in certain historical contexts. The combined activities of the state and university authorities have been critical in the generation and sustenance of cultism and violence on campuses. We also draw attention to the fact that cultism and violence are complex phenomena that involved varieties of motives and interests from various sectors of the society, including rival cults groups, other students, institution's authorities, law enforcement agents and the general society (Adelola, 1997). In addition, cultism membership is not restricted to students but includes members and financiers in influential positions in the society (Okwu, 2006). The eclipse of radical politics on campuses calls for revival of the 
cultures of debate and critical inquiry that would thwart the major bulwark against cultism and other forms of violence in Nigerian universities.

Furthermore, we discovered that academic success depends largely on order, peace, happiness of the learners and hard works. The students who desire success in their academic studies must learn hard work and practice order. These are the expectations and requirements of the peaceable university. The students' success in their studies depends also on their compliance to the moral obligations of the six rights (6Rs) which governs the absolute rightness of an action in the university. The rights insist on the completeness of the rightness of an action. Thus, for an action to be right, the six moral conditions have to be fulfilled legitimately, logically and positively. These six rights or moral conditions include: The right person, the right thing, the right reason, the right way, the right time and the right place. This means that the six rights do not accept partial rightness of an action.

\section{References}

Adejumobi, S. (2005). From Unionism to Cultism: The Recomposition of Student Identity. In B. Beckman, \& Y. Z. Ya'u (Eds.), Great Nigerian Students: Movement; Politics and Radical Nationalism. Kano: Centre for Research and Documentation and Politics Development Group.

Adelola, I. (1997). Secret cults in Nigerian institutions of learning: A periscopal appraisal. In OA Ogunba-meru (Ed.), Reading on Campus Secret Cults. Ile-Ife: Obafemi Awolowo University Press Ltd.

Adesogan, E. K. et al. (2002). University of Ibadan Vision for the 21st Century: Committee Reports. Ibadan: University of Ibadan.

Adewale, R. (2005). Violence in citadel: The Menace of Secret Cults in Nigeria Universities. Nordic Journal of African Studies, 14(1).

Ayu, I. D. (1986). Essays in Popular Struggle: Fela, Students Patriotism and Nicaraguan Revolution. Owerri: Zim Pan African Publishers.

Bagu, C. (2005). Students' Power at the University of Jos. In B. Beckman, \& Y. Z. Ya'u (Eds.), Great Nigerian Students: Movement; Politics and Radical Nationalism. Kano: Centre for Research and Documentation and Politics Development Group.

Beardmore, R. W. (1969). Moral Reasoning. London: Routledge and Kegan Paul Limited.

Beckman, B. (2005). Students Radicalism and the National Project. In B. Beckman, \& Y. Z. Ya'u (Eds.), Great Nigerian Students: Movement; Politics and Radical Nationalism. Kano: Centre for Research and Documentation and Politics Development Group.

Bremer, S. N. (1967). How To Get What You Want. Lexington: Successful Achievement Inc.

Crabb Jr., L.G. (179). Basic Principles of Biblical Counseling. Grand Rapids: Zondervan Publishing House.

Daddieh, C. K. (1996). Universities and Political Protest in Africa: The Case of Cote d'Ivoire. 
Issue: A Journal of Opinion, 23(1), 57-60.

Diuba, J. J. (2004). Students and the Struggle against Authoritarianism in University Governance in Nigeria. In P. T. Zeleza, \& A. Olukoshi (Eds.), African Universities in the Twenty-First Century vol. II: Knowledge and Society.

Dzurgba, A. (1998). Student Demonstrations and Crisis in Nigerian Universities: Management and Solutions. Dept. of Rel. Studies, University of Ibadan.

Dzurgba, A. (2002). Cumulative Grade Points Average (CGPA). Ibadan: Department of Religious Studies, Faculty of Arts, University of Ibadan.

Dzurgba, A. (2004). Violence and Bloodshed in Nigerian Universities: A Search for Peace and Academic Excellence. Ibadan: John Archers Publishers.

Dzurgba, A. (2010). Management and Resolution of Conflict: Local and International Perspectives. Ibadan: John Archers (Publishers) Limited.

Ibeh, A. E. (2005). The Psycho-sociological Imperatives of Cultism in Nigerian Institutions of higher learning. Being a Paper Presented at a Seminar on Cultism and Its Effects on Nigerian Institutions of Higher Learning. Nov. 23 and 24

Jamiu, H. (2008). The Rising Wave of Cultism in Nigeria Universities. Daily Independent, 18th November.

Kalu, V. (1995). The Leadership Question. Enugu, Hilly's Press.

Kelley, O. (2001). The Definition of Cultism. In W. A. Akinfolarin(Ed.), Combating Cultism in Nigeria's Institutions of Higher Learning: The roles of the library. Educational Thought, 3(1): 297-304.

Kuna, M. J. (1996). State Intervention and University Autonomy: The Case of the National Universities. Proceedings of the 9th General Social Science General Assembly of Nigeria (Michael Obadan Ed.), 1-20. Ibadan: Social Science General Assembly.

Kuna, M. J. (2003). The Academic Ethic and the Spirit of Opportunism: Commitment, Criticism and Responsibility in University Education. Ethics in Higher Education in Nigeria, 92-100. Abuja: Social Science Academy of Nigeria.

Mustapha, A. R. (1991). Structural Adjustment and Multiple Modes of Social Livelihood in Nigeria. United Nations Research Institute for Development (Geneva) Discussion Paper 26, $1-27$.

Ochoche, S. A. (1997). Electoral Violence and National Security in Nigeria. Africa Peace Review, Journal of the Centre for Peace and Conflict Resolution, 1(1). https://doi.org/10.1111/0149-0508.00035

Okafor, J. N. (2003). The New Martyrdom. Issues of Violence in Nigeria. Awka: Mercury Bright Press.

Okwu, O. J. (2006). A Critique of Students' Vices and the Effect on Quality of Graduates of 


\section{Macrothink}

Nigerian Tertiary Institutions. Journal of Social Sciences, 12(3). https://doi.org/10.1080/09718923.2006.11978391

Onuogha, P. (1998). Cultism and Violence. Ways of checking them, Champion 27th june. Pp18, 19, and 28.

Smith, D. J. (2004). The Bakassi Boys: Vigilantism, Violence, and Political Imagination in Nigeria. Cultural Anthropology, 19(3), 429-455. https://doi.org/10.1525/can.2004.19.3.429

Sutherland, E. H., \& Cressey, D. R. (1976). Two Types of Explanations of Criminal Behaviour. In A. C. Lewis, \& B. Rosenberg (Eds.), Sociological Theory: A Book of Readings (pp. 470-474). New York: Macmillan Publishing Co., Inc.

Ubani, C. (2005). Nsukka: Recollections from an Interlude of Struggle. In B. Beckman, \& Y. Z. Ya'u (Eds.), Great Nigerian Students: Movement; Politics and Radical Nationalism. Kano: Centre for Research and Documentation and Politics Development Group.

Ugbudian, L. I. (2015). Occupy Nigeria: Paradigm Shift in Mass Resistance. Frankfurt: Peter Lang.

Ya'u, Y. Z. (2005). The Nigerian Student Movement: A Review of Issues and Literature. In B. Beckman, \& Y. Z. Ya'u (Eds.), Great Nigerian Students: Movement; Politics and Radical Nationalism. Kano: Centre for Research and Documentation and Politics Development Group.

\section{Copyright Disclaimer}

Copyright reserved by the author(s).

This article is an open-access article distributed under the terms and conditions of the Creative Commons Attribution license (http://creativecommons.org/licenses/by/3.0/). 